\title{
Aplikasi Praktis dan Mudah Mengenali Gejala Anak Autisme Sejak Dini
}

DOI: https://doi.org/10.32509/abdimoestopo.v5i1.1769

\author{
Ricko Irawan $^{1 *}$, Agus Raharjo ${ }^{2}$, Aris Mulyono ${ }^{3}$, Sesaria Nisa Afifi ${ }^{4}$ \\ Pendidikan Jasmani Kesehatan dan Rekreasi, Fakultas Ilmu Keolahragaan \\ Universitas Negeri Semarang \\ Jl. Sekaran, Gunungpati Semarang 50229, Indonesia \\ *Email korespondensi: rickoirawan@mail.unnes.ac.id.
}

\begin{abstract}
Autism can strike children at any time, many children who actually from an early age have experienced symptoms of autism but due to late identification, this disease is difficult to cure. The purpose of introducing the SDA-03 application is to introduce the characteristics of children who experience early symptoms of autism to parents or families whose sons / daughters are affected by autism, because it is very possible if one family is affected by autism, other families can also experience the disease. the same one. Autism must be recognized as early as possible, because recognizing it early will make it easier to take steps for handling and treatment. This application is in the form of software which contains a questionnaire consisting of 23 questions concerning the development of children aged 1 to 3 years. This service uses an online model with the methods of a) material presentation, b) discussion and 3) evaluation. This service activity involves 40 teachers, education staff and school principals. The introduction of the SDA-03 application provides an understanding for teachers and parents on how to deal with children with autism from an early age. After the SDA-03 socialization was carried out at the Salatiga City SLB school, the need for socialization on an even larger scale.
\end{abstract}

Keywords: Autism, Software Detection Autism-03, Early Childhood.

Abstrak Penyakit autisme dapat menyerang anak kapan saja, banyaknya anak yang sebenarnya sejak usia dini sudah mengalami gejala autisme tetapi dikarenakan identifikasi yang terlambat maka penyakit ini sulit untuk disembuhkan. Tujuan pengenalan apikasi SDA-03 untuk mengenalkan ciri-ciri anak yang mengalami gejala dini auitsme pada orang tua atau keluarga yang putra/putrinya terdampak penyakit autisme, dikarenakan sangat memungkinkan jika ada salah satu keluarga yang terdampak penyakit autis maka keluarga yang lain juga bisa mengalami penyakit yang sama. Penyakit autisme harus dikenali sedini mungkin, karena dengan mengenali sejak dini akan mempermudah melakukan langkah penanganan dan pengobatan. Aplikasi ini berupa software yang didalamnya berisi angket yang terdiri dari 23 butir pertanyaan yang menyangkut perkembangan anak dimulia usia 1 s.d 3 tahun. Pengabdian ini menggunakan model daring dengan metode a) pemaparan materi, b) diskusi dan 3) evaluasi. Kegiatan pengabdian ini melibatkan guru, tenaga pendidikan dan kepala sekolah yang berjumlah 40 orang. Dengan adanya pengenalan aplikasi SDA-03 memberikan pemahaman bagi guru dan orang tua bagaimana cara menangani anak auitisme sejak dini. Setelah dilakukan sosialisai SDA-03 di sekolah SLB Kota Salatiga perlunya sosialisai pada skala yang lebih besar lagi.

Kata Kunci: Autisme, Software Detection Autism-03, Anak Usia Dini 


\section{PENDAHULUAN}

Autisme mempunyai makna berdiri sendiri, anak autis mempunyai fantasi sendiri dalam kehidupannya sehingga sulit untuk memusatkan perhatian dan ketika berbicara tidak memandang lawan bicaranya. Gangguan TBR1 menimbulkan defisit bicara yang parah pada anak autisme (Zhao et al., 2007). Pengurangan akses informasi artikulatoris menjadi kontributor masalah komunikasi anak autisme (Irwin \& Brancazio, 2014). Seorang autisme mengalami gangguan pemusatan perhatian dan sulit berinteraksi dan bersosialisasi. Autis ditandai gangguan dan keterlambatan kemampuan kognitif, bahasa, prilaku dan interaksi sosial (Suteja, 2014). Defisit bahasa ekspresif akibat fungsi penurunan oromotor (Belmonte et al., 2013). Keseimbangan optimal eksitasi dan inhibsi anak autisme mengalami gangguan (Humphreys et al., 2008); (Yizhar et al., 2011); (Zikopoulos \& Barbas, 2013). Banyak penelitian melaporkan bahwa anak autisme mengalami gangguan memori kerja (Schuh \& Eigsti, 2012).

Anak autis sangatlah unik mempunyai karakter senang menyendiri dan bersikap apatis terhadap lingkungan. Anak autis mengalami defisit timbal balik sosial (Xia et al., 2010). Pada usia balita respons terhadap lingkungan sekitar sangatlah rendah. Anak autisme jarang sekali tersenyum dan berbicara sangat terbatas. Perkataannya tidak jelas untuk dimaknai dan cenderung tidak menyukai suara dari luar. Anak autisme cenderung membeo dan senang melakukan stimulasi diri sendiri tetapi tidak lazim seperti anak pada usianya semisal memukulmukul kepala atau anggota badan sendiri tanpa sebab yag jelas. Autisme merupakan gangguan komunikasi verbal dan non verbal yang rumit (Desoky et al., 2017) Anomali fisik minor gangguang perkembangan syaraf sering terjadi pada anak autisme (Cheung et al., 2011). Kelain motorik merupakan endofenotipe yang kuat pada gangguan spectrum autisme (Esposito \& Paşca, 2013).

Penyandang autisme mempunyai cara pandang dan berprilaku berbeda dengan anak seusianya, mereka cenderung berfikir dan berprilaku sesuai dengan kemamuannya sendiri (Nair et al., 2013) autisme biasnya melibatkan gangguan konektivitas. Mereka sulit diatur dan sulit diarahkan. Hal ini disebabkan karena mereka mempunyai kebutuhan personal tersendiri. Anak autisme mempunyai dunianya sendiri dan menanggapi sesuatu berdasarkan presepsi mereka sendiri sehingga sulit menerima realitas kehidupan yang sebenarnya.

Anak yang mengalami autisme cenderung menutup diri dari dunia luar. Anak autis mengalami problematika gangguan komunkasi, perilaku dan interaksi (Puspita, 2003). Anak autisme cenderung terisolir dari pergaulan hidup teman sebayanya, karena kebiasaan yang abnormal secara fisik maupun mental menyebabkan orang disekitar enggan untuk bermain dengan anak autisme. Terjadinya penyimpangan tumbuh kembang anak autisme secara tidak normal (Nafi, 2016). Kenyataan ini tentunya sangatlah tidak menguntungkan bagi perkembangan anak autis jika terjadi secara terus menerus, karena tentunya akan menghambat tumbuh kembang anak tersebut di masa mendatang.

Anak autisme cenderung terisolasi dengan manusia dan masuk dalam dunia respetitiv, aktivitas dan minat obsesif (Setyaningsih, 2016). kadang mereka tidak bisa mengontrol emosinya secara baik (Khoirunnisa \& Nursalim, 2012) sehingga dapat mengakibatkan kerugian baik dirinya sendiri maupun orang lain. Identifikasi anak autis sangatlah penting sebagai langkah pencegahan dan pengobatan, dikarenakan jika identifikasi terlambat akan mempersulit proses penyembuhan dan pengobatan. Gangguan spectrum autisme merupakan gangguan yang heterogen yang menghadirkan tantangan untuk diagnosis dan pengobatan (Jeste \& Geschwind, 2014).

Gejala autis sejak dini sebenarnya sudah bisa "dicium" sejak dini, tetapi banyak orang tua yang tidak memahami. Dalam pengabdian ini penulis mengenalkan software SDA-03 yang bertujuan untuk mengidentifikasi gejala dini anak autisme usia 1-3 tahun. 


\section{METODE PELAKSANAAN}

Prosedur pelaksanaan diawali dengan tahap persiapan dan tahap pelaksanaan. Tahap persiapan pengabdian ini diawali tim melakukan koordinasi awal dengan kepala sekolah SLB Negeri Kota Salatiga Muhlisun, S.Pd., M.Pd. untuk memperoleh ijin pelaksanaan pengabdian serta agar melibatkan guru dalam proses kegiatan pengabdian tersebut. Setelah ada ijin secara lisan, tim segera melayangkan surat permohonan secara formal ke Kepala Sekolah pada tanggal 19 Maret 2021. Pada tanggal 26 Maret 2021 pihak sekolah mengirimkan surat kesediaan bekerjasama dengan tim pengabdi. Setelah itu tim pengabdi dan pihak sekolah segera menentukan waktu pelaksanaan pengabdian kepada masyarakat pada tanggal 16 dan 17 September 2021. Pihak sekolah yang mengatur peserta kegiatan dan tim pengabdian yang mempersiapkan teknis pelaksanaan kegiatan.

Tahap pelaksanaan sosialisasi mengingat masih dalam masa pandemi Covid-19 maka dilakukan secara daring menggunakan media zoom meeting, tim pelaksana meyampaikan materi terkait teori autisme dan aplikasi identifikasi anak autisme secara virtual. Walaupun demikian pelaksanaan berjalan tertib dan lancar karena kerjasama yang baik antara pihak sekolah dan tim pengabdian. Kegiatan pengbabdian ini dihadiri 40 peserta yang terdiri dari guru, tendik dan Kepala Sekolah SLB Negeri kota Salatiga. Kegiatan ini oleh pihak sekolah dijadikan sarana edukasi bagi guru, tendik dan Kepala Sekolah dalam memperluas informasi deteksi dini anak autisme melalui alat berbasis android. Program ipteks dijadikan guru dan orang tua sebagai alat edukasi untuk mengasuh anak (. et al., 2015).

Metode Pengabdian Kepada Masyarakat yang dilakukan menggunakan metode pemaparan materi, diskusi dan evaluasi. Pada paparan materi tanggal 16 September 2021, tim pemateri memberikan materi menjadi dua sesi. Sesi pertama berupa teori anak autisme dimulai dari pengertian, sejarah, jenis-jenis, penyebab, karakteristik, dan penanganan anak autis. Pengertian anak autis sendiri adalah suatu kondisi kecacatan pada perkembangan syaraf sebelum usia 3 tahun yang ditandai dengan defisit timbal balik sosial dan dalam keterampilan bahasa (Xia et al., 2010). (Nugraheni, 2012) mendifinisikan bahwa autisme adalah gangguan perkembangan yang sangat kompleks yang menjadi misteri dunia kedokteran sejak dulu. Sejarah autisme terjadi tahun 1943 ketika seorang Psikater (Leo Kanner) yang menjabarkan secara rinci gejala-gejala aneh yang ditemukan pada 11 pasien kecilnya. Leo Kanner menemukan bahwa anak-anak tersebut sangat asik dengan dunianya sendiri sehingga istilah autisme diartikan sebagai hidup di dunianya sendiri (Mutia, 2018). Jenis-jenis autis atau ADHD ada 3 yaitu Inattention, Implusif dan Hyperactivity (Fadila \& Ratnawati, 2016). Penyebab anak autisme menjadi perdebatan para pakar, seperti faktor patofisiologi dan gen (Jeste \& Geschwind, 2014). Beberapa peneliti menyebutkan penyebab autisme seperti amigdala, hipokampus, serebelum dan lobus temporalis (Wardhani \& Sudjudi, 2014). Anak autisme memiliki karakteristik: 1) gangguan komunikasi verbal dan non verbal, 2) gangguan interaksi sosial, 3) gangguna prilaku bermain, 4) gangguan emosi dan perasaan, dan 5) gangguan persepsi sensoris (Angayasti, 2012). Penanganan anak autisme bisa menggunakan terapi tingkah laku, terapi wicara, pendidikan berkebutuhan khusus dan terapi okupasi (Hasnita \& Hidayati, 2017).

Sesi kedua pemateri memaparkan Sofware Detection Autism-03. Langkah-langkah penggunaan software meliputi : login, mengisi data awal, mengisi angket yang berisi 23 pertanyaan dan melihat hasil. Pada halaman login peserta harus memasukkan user dan pasword yang telah disediakan oleh tim pelaksana. Setelah berhasil login, peserta mengisi data awal anak yang akan diamati yaitu berupa: nama anak dan usia. Setelah mengisi data kemudian peserta mengisi 23 pertanyaan yang sudah tersedia oleh aplikasi tentunya dengan mengamati tingah laku anak saat usia 1 s.d 3 tahun yang menjadi terget pengamatan. Setelah ke-23 
pertanyaan telah terisi maka peserta bisa mengakhiri halaman pertanyaan dan kemudian hasil secara otomatis akan muncul (apakah anak ada indikasi autis atau tidak). Hasil Software SDA03 ini bersifat rekomendasi bukan kesimpulan artinya jika ada anak terindikasi mengalami gejala autisme, maka orang tua atau peserta harus segera memeriksakannya kepada ahli yaitu dokter atau psikolog agar dilakukan pemeriksaan lebih lanju. Software ini bisa dikatakan sebagai alat penunjang di dalam mendeteksi gejala awal anak dengan gejala autisme sejak dini, sehingga diharapkan bisa memberikan konstribusi di dunia kesehatan utamanya pada anak autisme.

Setelah pemateri selesai paparan peserta diberi kesempatan untuk melakukan sesi tanya jawab. Sesi diskusi berjalan dengan cair dan ada masukan yang positif dari beberapa peserta terkait dengan instrumen software yang dikembangkan. Sementara ini memang instrumen yang dihasilkan tim pengabdi masih secara umum untuk mendeteksi anak autisme usia 1 s.d 3 tahun. Peserta memberi masukan agar instrumen lebih dispesifikasikan lagi menurut kriteria usia masing-masing, dikarenakan usia perkembangan anak usia 1 tahun tentunya berbeda dengan anak usia 2 dan 3 tahun.

Evaluasi kegiatan dilakukan pada hari kedua tanggal 17 September 2021, setelah peserta melakukan uji coba software. Evaluasi dilakukan dengan memberikan informasi tentang jawaban mana yang mengandung unsur anak yang mengalami gejala autis atau tidak. Pemateri membahas semua soal yang ada di angket satu per satu. Sehingga peserta menjadi lebih jelas makna dari soal yang ada pada angket tersebut. Pemateri pada hari kedua juga memberikan evaluasi kepada peserta yang belum bisa mengoperasikan software. Ada 3 peserta karena usia sehingga tidak familiar menggunakan gagjet, sehingga tim dengan telaten membimbing peserta tersebut pelan-pelan agar bisa mengoperasikan software tersebut.

\section{HASIL DAN PEMBAHASAN}

Antusiasme peserta pengabdian sangatlah tinggi, terjadi interaksi yang positif dengan berbagi pengetahuan tentang anak autiisme. Hal ini memberikan motivasi ekstra pada tim dalam mengisi kegiatan pengabdian. Peserta mengharapkan ada keberlangsungan sosialisasi secara berkesinambungan dan berharap akan ada seminar atau webinar tentang anak autisme sehingga peserta mempunyai tambahan baru informasi dan ilmu yang bermanfaat.

Sebelum kegiatan pengabdian dilaksanakan, diketahui melalui proses wawancara dengan kepala sekolah dan beberapa guru di SLB kota Salatiga bahwa di sekolah tersebut sudah ada instrumen untuk melihat anak autis dengan kategori ringan, sedang sampai berat yang dikembangkan akademisi dari Universitas Diponegoro. Tetapi aplikasi deteksi gejala awal anak autisme belum ada di sekolah tersebut. Peserta juga memberi masukan akan pentingnya menjalin kerjasama dan komunikasi dengan pelayanan kesehatan yang ada di wilayah terdekat seperti Puskesmas, sehingga Puskesmas diharapkan bisa memberikan konstribusi di dalam menyebarkan berita yang terkait dengan anak autisme sehingga memudahkan masyarakat awan jika ada anak atau keluarga yang mengalmi gejala autisme sejak dini. Seperti yang dikemukakan (Dewi et al., 2018) pada jurnal Abdi Moestopo tentang perlunya fungsi promotif dan preventif pada kader-kader Puskesmas di dalam memberikan pemanfaatan dan pengetahuan media komunikasi untuk promosi kesehatan.

Tim menyimpulkan hasil indikator ketercapaian kegiatan pengabdian ini sangatlah tinggi atau sekitar 92,5\% tercapai tujuannya yaitu 38 peserta mayoritas bisa mengoperasionalkan aplikasi atau software SDA-03 berbasis android untuk mendeteksi anak autis sejak usia dini. Sedangkan 3,8\% atau 3 peserta tidak bisa mengoperasikannya karena faktor usia. Menurut peserta dengan memanfaatkan gadjet memberikan kemudahan guru apabila ada gejala ganjil di masa perkembangan anak. Guru juga bisa menjadi influecer di lingkungan rumah masing- 
masing untuk mensosialisasikan software yang telah dikembangkan ini. Indikator ketercapain kegiatan pengabdian bisa dilihat pada gambar 1 .

\section{Indikator Ketercapaian}

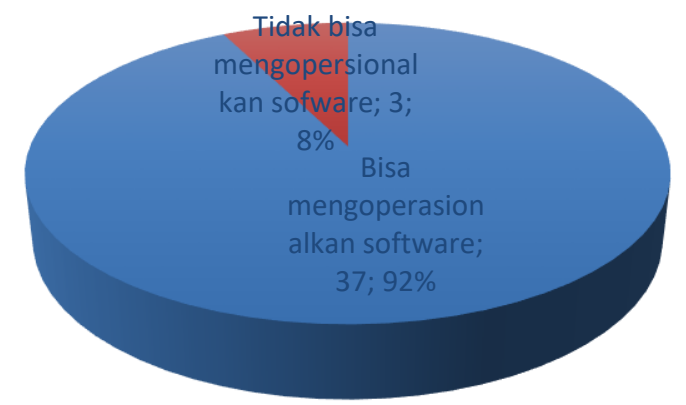

- Bisa mengoperasionalkan software $\mathbf{T}$ Tidak bisa mengopersionalkan sofware

Gambar 1. Indikator ketercapaian kegiatan pengabdian

Peserta sangat aktif dalam mengikuti kegiatan pelatihan secara daring maupun saat sesi diskusi tanya jawab (lihat gambar 2). Hal positif yang dapat diperoleh setelah kegiatan pengabdian selesai dilaksanakan adalah ternyata setelah mengikuti kegiatan ini, peserta merasa senang dan langsung bisa mengoperasionalkan software SDA-03 untuk mendeteksi anak usia dini. Disamping itu juga setelah diadakan kegiatan ini peserta berharap segera dibuatkan akun software bagi masing-masing peserta sehingga lebih mudah dalam mensosialisaiakan software kepada orang lain.

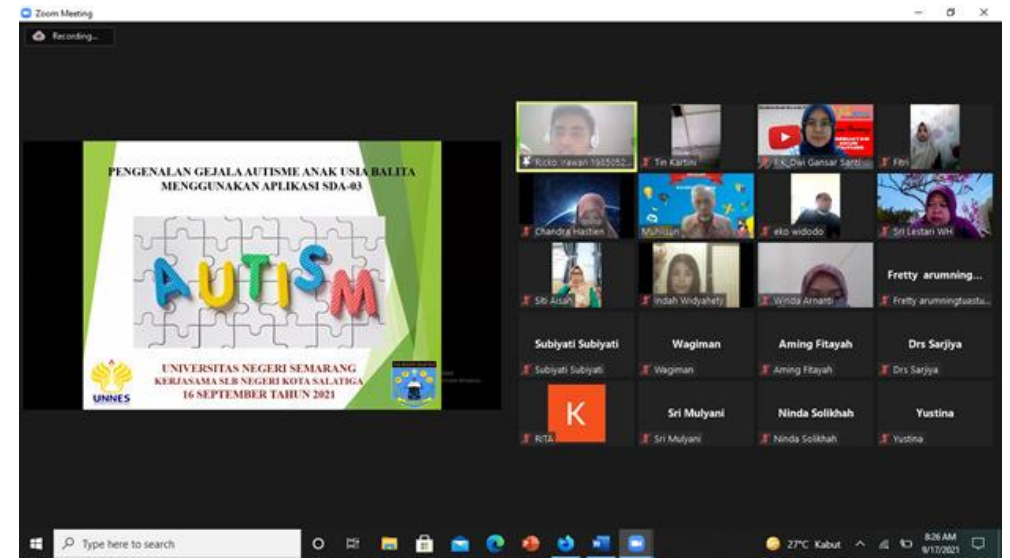

Gambar 2. Baground kegiatan pengabdian secara online

Instrumen yang digunakan pada pengabdian ini merupakan hasil penelitain tim pengabdi yang dikembangkan pada tahun 2016 dengan judul "Aplikasi SDA (Software Detection Autism) Untuk Mendeteksi Penyandang Autisme Sejak Usia Dini”. Instrumen ini sudah diuji kelayakannya oleh 3 ahli yang terdiri dari ahli okupasi, ahli psikologi, dan dosen pendidikan berkebutuhan khusus. Instrumen terdiri dari angket berupa 23 pertanyaan yang harus dijawab oleh responden dengan mengamati perilaku anak yang menjadi objek observasi. Angket merupakan instrumen utama untuk menentukan ada atau tidaknya seorang anak yang terindikasi mengalami gejala autisme. Instrumen ini dikembangan dari hasil adaptasi dari buku "Pantang Menyerah Mengasuh Asih Anak Berkebutuhan Khusus" (Nafi, 2016). Instrumen dapat dilihat pada tabel 1 di bawah ini: 
Tabel 1. Bentuk Adaptasi Instrumen Penilaian Anak Autisme Dian Nafi

\begin{tabular}{|c|c|c|c|c|}
\hline \multirow{2}{*}{ No } & \multirow[t]{2}{*}{ Pertanyaan } & \multicolumn{3}{|c|}{ Jawaban } \\
\hline & & Normal & YA/TIDAK & Autisme \\
\hline 1. & $\begin{array}{l}\text { Anak suka bermain dengan } \\
\text { temannya }\end{array}$ & ya & & tidak \\
\hline 2. & Anak suka diayun & ya & & tidak \\
\hline 3. & $\begin{array}{l}\text { Anak suka memanjat (kursi, } \\
\text { meja, tangga) }\end{array}$ & ya & & tidak \\
\hline 4. & $\begin{array}{l}\text { Anak suka permainan } \\
\text { cilukba }\end{array}$ & ya & & tidak \\
\hline 5. & $\begin{array}{l}\text { Anak berbicara dengan } \\
\text { boneka atau pura-pura } \\
\text { berbicara di telepon }\end{array}$ & ya & & tidak \\
\hline 6. & $\begin{array}{l}\text { Anak menggunakan } \\
\text { telunjuk meminta sesuatu }\end{array}$ & ya & & tidak \\
\hline 7. & $\begin{array}{l}\text { Anak saat diberikan mainan } \\
\text { tidak dijatuhkan begitu saja }\end{array}$ & ya & & tidak \\
\hline 8. & $\begin{array}{l}\text { Anak pernah membawa } \\
\text { objek/benda diperlihatkan } \\
\text { kepada Anda }\end{array}$ & ya & & tidak \\
\hline 9. & $\begin{array}{l}\text { Anak melihat mata Anda } 1 \\
\text { s.d } 2 \text { detik ketika bercanda }\end{array}$ & ya & & tidak \\
\hline 10. & $\begin{array}{l}\text { Anak tersenyum saat kita } \\
\text { tersenyum }\end{array}$ & ya & & tidak \\
\hline 11. & $\begin{array}{l}\text { Anak memberikan reaksi } \\
\text { ketika nama dipanggil }\end{array}$ & ya & & tidak \\
\hline 12. & $\begin{array}{l}\text { Anak menirukan jika Anda } \\
\text { membuat raut wajah } \\
\text { tertentu }\end{array}$ & ya & & tidak \\
\hline 13. & $\begin{array}{l}\text { Anak merespons saat Anda } \\
\text { menunjuk mainan di sisi } \\
\text { ruang tertentu }\end{array}$ & ya & & tidak \\
\hline 14. & $\begin{array}{l}\text { Anak usia } 2,5 \text { tahun sudah } \\
\text { bisa berjalan }\end{array}$ & ya & & tidak \\
\hline 15. & $\begin{array}{l}\text { Anak melihat pada benda } \\
\text { yang Anda lihat }\end{array}$ & ya & & tidak \\
\hline 16. & $\begin{array}{l}\text { Anak mencoba mencari } \\
\text { perhatian pada aktivitas } \\
\text { yang dia lakukan pada Anda }\end{array}$ & ya & & tidak \\
\hline 17. & $\begin{array}{l}\text { Anak mengerti apa yang } \\
\text { orang lain katakan }\end{array}$ & ya & & tidak \\
\hline 18. & $\begin{array}{l}\text { Anak melihat wajah Anda } \\
\text { (ingin melihat reaksi Anda) } \\
\text { ketika dia dihadapkan pada } \\
\text { situasi yang asing atau saat } \\
\text { dia didak mengerti }\end{array}$ & ya & & tidak \\
\hline 19. & $\begin{array}{lll}\text { Anak menolak } & \text { untuk } \\
\text { dipeluk } & & \end{array}$ & tidak & & ya \\
\hline
\end{tabular}


20. Anak cuek ketika dipanggil (tidak menengok) menangis dan tertawa tanpa sebab

21. Anak suka memasukkan mainan ke mulutnya

22. Anak tidak bisa bermain dengan teman sebaya

23. Ekspresi anak kurang hidup tidak

ya

tidak

ya

tidak

ya

tidak

ya

Penomoran pada tabel nomor 1 s.d 18 menjelaskan bahwa jawaban "ya" adalah jika anak pada indikator normal, sedangkan jawaban "tidak " artinya anak terindikasi mengalami gejala autisme. Nomor 19 s.d 23 menyimpulkan bahwa jawaban "tidak" artinya anak terindikasi normal atau tidak ada gejala autisme, sedangkan jawaban "ya" mengemukakan bahwa anak ada indikasi mengalami gangguan autisme. Diagnosis anak mengalami gejala autisme dapat ditegakkan apabila minimal ada 3 gejala yang muncul.

\section{SIMPULAN}

Pengenalan Software Detection Autisme SDA-03 memberikan manfaat langsung kepada guru tentang pengenalan gejala anak autisme serta memberikan informasi yang detail cara mendeteksi anak autisme sejak dini. Guru sekarang sudah mempunyai akses yang mudah melalui media Android tentang bagaimana cara mengidentifikasi anak yang berpotensi mengalami gejala autisme sejak dini.

Sosialisasi aplikasi SDA-03 dapat lebih diperluas lagi dengan skala yang lebih besar dengan mengundang masyarakat umum pada skala yang lebih tinggi tingkat Jawa Tengah. Tim pengabdi harus selalu gigih mengiklankan aplikasi ini sehingga dapat dikenal oleh masyarakat luas dengan memanfaatkan media online seperti instagram, facebook, twiter atau media online lainnya. Guru yang sudah dapat mengakses aplikasi SDA-03 diharapkan menjadi pionie-pionir untuk mensosialisasikan produk ini sehingga dapat dimanfaatkan oleh orang lain.

Pelunya kerjasama dengan pihak - pihak kesehatan seperti Puskesmas di wilayah perkampungan terdekat agar bisa memberi informasi yang mudah, cepat dan akurat jika ada masyarakat yang membutuhkan informasi tentang deteksi anak autisme sejak dini beserta penanganannya menggunakan aplikasi android, sehingga akan meminimalisir terjadinya anak autisme dengan gejala berat. Dikarenakan deteksi sedini mungkin pada anak autisme memungkinkan anak mudah untuk ditangani pada masa yang akan datang.

\section{Ucapan Terima Kasih}

Ucapan terima kasih kami sampaikan kepada Lembaga Penelitian dan Pengabdian Masyarakat (LP3M) Universitas yang telah mendanai kegiatan dari awal sampai selesai. Tak lupa ucapan terima kasih juga kami sampaikan kepada kepala sekolah SLB Negeri Kota Salatiga beserta guru, dan tenaga kependidikan yang telah bekerjasama dengan tim pengabdi dengan apik sehingga pelaksanaan pengabdian dapat berjalan dengan lancar.

\section{Daftar Pustaka}

. R., Hartini, T., Prasetyo, A., . V., \& Mushafanah, Q. (2015). IBM PARENTING BAGI GURU DAN ORANG TUA PAUD DI KELURAHAN PUDAK PAYUNG SEMARANG. $E$ DIMAS, 6(2), 35. https://doi.org/10.26877/e-dimas.v6i2.960

Angayasti, A. R. (2012). Analisis Gambar Anak Berkebutuhan Khusus (Autis) SD Plus Al- 
Ghifari Tahun Ajaran 2010-2011 Kota Bandung. Universitas Pendidikan Indonesia. http://repository.upi.edu/10442/

Belmonte, M. K., Saxena-Chandhok, T., Cherian, R., Muneer, R., George, L., \& Karanth, P. (2013). Oral motor deficits in speech-impaired children with autism. Frontiers in Integrative Neuroscience, 7, 47. https://doi.org/10.3389/fnint.2013.00047

Cheung, C., McAlonan, G. M., Fung, Y. Y., Fung, G., Yu, K. K., Tai, K.-S., Sham, P. C., \& Chua, S. E. (2011). MRI Study of Minor Physical Anomaly in Childhood Autism Implicates Aberrant Neurodevelopment in Infancy. PLoS ONE, 6(6), e20246. https://doi.org/10.1371/journal.pone.0020246

Desoky, T., Hassan, M. H., Fayed, H., \& Sakhr, H. M. (2017). Biochemical assessments of thyroid profile, serum 25-hydroxycholecalciferol and cluster of differentiation 5 expression levels among children with autism. Neuropsychiatric Disease and Treatment, Volume 13, 2397-2403. https://doi.org/10.2147/NDT.S146152

Dewi, R., Dida, S., \& Anisa, R. (2018). Pelatihan Komunikasi Bagi Kader Posyandu di Desa Pegerwangi, Kecamatan Lembang, Kabupaten Bandung Barat-Jawa Barat. Jurnal Abdi MOESTOPO, 1(02), 58-65. https://doi.org/https://doi.org/10.32509/am.v1i02.522

Esposito, G., \& Paşca, S. P. (2013). Motor abnormalities as a putative endophenotype for Autism Spectrum Disorders. Frontiers in Integrative Neuroscience, 7, 43. https://doi.org/10.3389/fnint.2013.00043

Fadila, P. N., \& Ratnawati, D. E. (2016). Identifikasi Jenis Attention Deficit Hyperactivity Disorder (ADHD) Pada Anak Usia Dini Menggunakan Metode Neighbor Weighted KNearest Neighbor (NWKNN). Jurnal Teknologi Informasi Dan Ilmu Komputer, 3(3), 193-200. https://jtiik.ub.ac.id/index.php/jtiik/article/view/195/pdf

Hasnita, E., \& Hidayati, T. R. (2017). Terapi Okupasi Perkembangan Motorik Halus Anak Autisme. Jurnal Ipteks Terapan, http://ejournal.lldikti10.id/index.php/jit/article/view/25/24

Humphreys, K., Hasson, U., Avidan, G., Minshew, N., \& Behrmann, M. (2008). Cortical patterns of category-selective activation for faces, places and objects in adults with autism. Autism Research, 1(1), 52-63. https://doi.org/10.1002/aur.1

Irwin, J. R., \& Brancazio, L. (2014). Seeing to hear? Patterns of gaze to speaking faces in children with autism spectrum disorders. Frontiers in Psychology, 5, 397. https://doi.org/10.3389/fpsyg.2014.00397

Jeste, S. S., \& Geschwind, D. H. (2014). Disentangling the heterogeneity of autism spectrum disorder through genetic findings. Nature Reviews Neurology, 10(2), 74-81. https://www.nature.com/articles/nrneurol.2013.278

Khoirunnisa, R. N., \& Nursalim, M. (2012). Studi Kasus Dinamika Emosi Pada Anak Autis. Jurnal Psikologi Teori Dan Terapan, 2(2), 108. https://doi.org/10.26740/jptt.v2n2.p108120

Mutia, F. (2018). Kemampuan anak autis menyerap informasi melalui proses belajar di sekolah inklusi. http://journal.unair.ac.id/download-fullpapers-palim4f33d9ae81full.pdf

Nafi, D. (2016). Pantang Menyerah Mengasuh Asih Anak Berkebutuhan Khusus. In Familia. https://opac.perpusnas.go.id/DetailOpac.aspx?id=1020391

Nair, A., Treiber, J. M., Shukla, D. K., Shih, P., \& Müller, R.-A. (2013). Impaired thalamocortical connectivity in autism spectrum disorder: a study of functional and anatomical connectivity. Brain, 136(6), 1942-1955. https://doi.org/10.1093/brain/awt079

Nugraheni, S. A. (2012). Menguak belantara autisme. Buletin Psikologi, 20(1-2), 9-17. file://C:/Users/RIKO/Downloads/11944-23346-1-SM (2).pdf

Puspita, D. (2003). Kiat Praktis Mempersiapkan dan Membantu Anak Autis Mengikuti Pendidikan di Sekolah Umum. Seminar Mandiga, 22. https://adoc.pub/kiat-praktismempersiapkan-membantu-anak-autis-mengikuti-pen.html 
Schuh, J. M., \& Eigsti, I.-M. (2012). Working Memory, Language Skills, and Autism Symptomatology. Behavioral Sciences, 2(4), 207-218. https://doi.org/10.3390/bs2040207

Setyaningsih, W. (2016). Hubungan Pola Asuh Orang Tua dengan Perkembangan Sosial Anak Autisme di SLB Harmoni Surakarta. Jurnal Kesehatan, 6(2). https://doi.org/http://dx.doi.org/10.26630/jk.v6i2.92

Suteja, J. (2014). Bentuk dan metode terapi terhadap anak autisme akibat bentukan perilaku sosial. Edueksos: Jurnal Pendidikan Sosial \& Ekonomi, 3(1). https://www.syekhnurjati.ac.id/jurnal/index.php/edueksos/article/view/325/287

Wardhani, R. K., \& Sudjudi, I. (2014). Perancangan Video Dokumenter “Autisme.” Visual Communication Design, 3(1), 180546. https://www.neliti.com/publications/180546/perancangan-video-dokumenterautisme\#tid-section-content

Xia, W., Zhou, Y., Sun, C., Wang, J., \& Wu, L. (2010). A preliminary study on nutritional status and intake in Chinese children with autism. European Journal of Pediatrics, 169(10), 1201-1206. https://doi.org/10.1007/s00431-010-1203-X

Yizhar, O., Fenno, L. E., Prigge, M., Schneider, F., Davidson, T. J., O'shea, D. J., Sohal, V. S., Goshen, I., Finkelstein, J., \& Paz, J. T. (2011). Neocortical excitation/inhibition balance in information processing and social dysfunction. Nature, 477(7363), 171-178. https://www.nature.com/articles/nature10360

Zhao, J., Hu, Q., Chen, Y., Luo, S., Bao, L., \& Xu, Y. (2007). A novel missense mutation in the paired domain of humanPAX9 causes oligodontia. American Journal of Medical Genetics Part A, 143A(21), 2592-2597. https://doi.org/10.1002/ajmg.a.31993

Zikopoulos, B., \& Barbas, H. (2013). Altered neural connectivity in excitatory and inhibitory cortical circuits in autism. Frontiers in Human Neuroscience, 7, 609. https://doi.org/10.3389/fnhum.2013.00609 